Household Headship and Nutritional Status of Toddlers: An

Examination of Malawian Data

\author{
By \\ Clara C. Chindime \\ Civil Society Coalition for Quality Basic Education \\ P.O. Box 30736, Lilongwe, Malawi \\ TEL: (265) 9380189 \\ FAX: (265) 1770229 \\ Email: ccmlamba@yahoo.com \\ and \\ Susie Ubomba-Jaswa \\ Health and Vital Statistics \\ Statistics South Africa \\ 170, Andries Street, Pretoria, 0002 \\ Email: yaakwabea@yahoo.com
}


http://aps.journals.ac.za

\title{
Household Headship and Nutritional Status of Toddlers: An Examination of Malawian Data
}

\author{
Clara C. Chindime \\ Civil Society Coalition for Quality Basic Education \\ Lilongwe, Malawi
}

And

Susie Ubomba-Jaswa

Health and Vital Statistics

Statistics South Africa

\begin{abstract}
The feminisation of poverty indicates that female-headed households (FHH) constitute a vulnerable socio-economic group generally considered as impoverished compared to male-headed households $(\mathrm{MHH})$. The interest in this paper is to examine whether the nutritional status of children in FHH differ significantly from that of children in $\mathrm{MHH}$. Anthropometric data on 1466 toddlers aged 12-59 months and several societal, household and individual variables from the Malawi Demographic Health Survey (MDHS) 1992 were used to find out the net impact of the sex of household head on stunting, under nutrition and wasting in the toddlers. The bivariate results show that children in FHH (stunted - 56.7\%; underweight - 33.3\%; wasted - 6.7\%) may not have poorer nutritional outcomes than their counterparts from $\mathrm{MHH}$ (stunted - 53.6\%; underweight - $31.3 \%$; wasted $-5.7 \%$ ) since the differences are not significant. However, a number of the background characteristics were significantly associated with the three indicators suggesting that the results on headship could be masked by the differentials shown in background characteristics. Furthermore, results from the logistic regression analysis suggest that economic status has the strongest relationship with stunting. Hence the likelihood that a child from a better economic status household will be stunted is $50 \%$ less likely compared to a child from a poor household. Besides economic status, the role of birth weight, child's age sanitation and the region in which the child lives were found to be important differentials in the nutritional status of toddlers in Malawi
\end{abstract}

Key words: Malawi, male-headed household, female-headed household, stunting, underweight, wasting. 


\section{Introduction}

At the close of the 20 $0^{\text {th }}$ century, virtually all countries in Sub-Saharan Africa have witnessed dramatic improvement in child health, which has contributed to the substantial decline in the mortality of preschool children. This decline was mainly due to greater access and utilisation of maternal and child health services particularly immunisation against the major childhood killer diseases such tetanus, whooping cough and measles. Thus in Malawi, childhood mortality has over the years seen some improvement despite the fact that it is among the highest in the world. In 1990 the underfive mortality was estimated to be 244 . A decade later, the estimate showed some decline - 175 in 2004. Despite such success stories, malnutrition in its various forms continues to be a great silent threat to child health and ultimately survival. Malnutrition is not only responsible for growth faltering but is strongly associated with a number of childhood diseases, impaired mental development and death. For example, it is estimated that in Malawi malnutrition is implicated in about $37 \%$ of all under-five deaths (National Statistical Office, 2001). Is Malawi, like many less developed countries, sitting with sick living children?

Malnutrition manifests itself in several forms such as inadequate intake of protein energy; deficiencies in micronutrients like iron, vitamin A, iodine, etc; under-nutrition as well as over-nutrition (obesity). Similarly, there are multiple immediate and underlying determinants of malnutrition that could be grouped as, societal, household and individual factors. These include residence, income, household food security and sanitation, decision making, allocation of resources, child care practices, breastfeeding and weaning practices, maternal characteristics (age and education), birth weight, age and ill-health of children. The complexity of the forms and determinants of malnutrition is reflected in the varying studies that seek to examine the extent to which these issues affect malnutrition of children within a specific context.

There are a variety of ways of measuring nutritional status of individuals and populations in order to identify those who are considered malnourished. One such common ways is the use of anthropometry whereby measurements of the body particularly height and weight are taken. These measurements are standardised into Z-scores by comparing them to a reference population. One such international reference population frequently used is the World Health Organization, National Centre for Health Statistics and Centre for Disease Control (WHO/NCHS/CDC) standard. Three standard indicators of nutritional status are given. Each indicator refers to different aspect of malnutrition. The indicators are: height-for-age that measures linear growth and assesses the impact of chronic 
malnutrition or stunting; weight-for-age is a composite measure that indicates overall under nourishment; weight-for-height describes current/recent malnutrition. The cut-off point of more than two standard deviations below the median of the reference population (>-2 SD) is considered as stunted for height-for-age; underweight for weight-for-age and wasted for weight-forheight.

Malawi has conducted four demographic health surveys (MDHS) namely: 1992, 1996, 2000 and 2004. With the exception of the 1996 survey, anthropometric measurements of heights and weights were collected on under-five children in the surveys. For many years, child malnutrition in all its forms suffered from a long period of official denial. Indeed during the one party era (pre 1994), the government of Malawi declared repeatedly that child malnutrition was not a problem in the country. Thus even though there is some decline in childhood mortality, abundant evidence through the MDHS and other studies clearly reveal that not only is malnutrition among children high but that no improvement has been made for more than a decade. The MDHS 1992 estimates of malnutrition in the under-five children are basically the same as MDHS 2000 and 2004. The prevalence of stunting, underweight and wasting were: $48 \%, 27 \%$ and $5 \%$ respectively. In 2000, the figures were $49 \%, 24 \%$ and $6 \%$. The latest data from the MDHS 2004 are basically the same $-48 \%, 22 \%$ and $5 \%$.

Malnutrition is generally countered among "the disease of the poor". According to the feminisation of poverty theory, female headed households tend to be poorer than male headed households. Evidence from Malawi seems to support this assumption. Female-headed households are the most vulnerable in that they are generally in a state of continuous deprivation disadvantaged in terms of land, labour, income and other services. About $30 \%$ of Malawi's rural households are female headed. Several factors are contributing to the growth of female-headed households. Besides the effects of HIV/AIDS, unemployment and the general economic crises are fuelling male migrations into "greener towns, cities and countries" leaving more women to be the main, at times, the sole economic providers for their households. With the exception perhaps of those who receive substantial regular remittances from husbands, the majority of the households are poor. Children, especially toddlers, tend to bear the brunt of such deprivation and poverty manifesting themselves in malnutrition, frequent illnesses, and death. 
However, despite the tendency of female households to be poor, other research findings indicate that children in $\mathrm{FHH}$ tend to have better nutritional outcomes than those from $\mathrm{MHH}$. Possible explanation is that women are more likely to spend their income on food and child welfare, while men spend more on personal consumption and on agricultural inputs. Better nutritional status of children in FHH has been associated with the absence of conflicts or negotiations with the male partner over the use of household resources (WFP, 1999; Pelletier \& Msukwa, 1991; Kennedy et al, 1992; Bovinic \& Gupta, 1994).

The availability of several levels of data collected in the surveys provides a good opportunity to assess the influence of some of the determinants on the malnutrition of children in Malawi. Besides the country reports a number of studies (Madise \& Mpoma, 1997; Madise, Mathews, Margetts, 1997) have been done on aspects of malnutrition in children using the MDHS data. However, none has examined the effect of household headship on the nutritional status of children. Analysis based on the 1992 MDHS data serves as a valuable baseline in monitoring the role of household headship in childhood malnutrition. This is the focus of this paper.

\section{Methodology}

Since the interest in this study is on toddlers, 1466 children aged 12 to 59 months were selected from the total number of 3235 children aged less than five years in the 1992 MDHS. A number of selected variables were used as background characteristics in the analyses to determine the impact of household headship on the three indicators of malnutrition - stunting, underweight and wasting. The groupings of the variables are as follows:

Headship: sex of household head (male, female)

Nutritional status: height-for-age (normal, stunted); weight-for-age (normal, underweight); weight-for height (normal, wasted)

Societal: region (Northern, Central and Southern); residence (urban, rural) Household: household size (large, small); source of water (piped, unpiped); toilet facility (any facility, no facility); economic status [proxy measure using type of floor] (poor [mud floor], not poor [non mud floor])

Individual: mother's age (young, old); mother's education (some schooling, no schooling); child's sex (male, female); child's age (young, old); child's birth weight (low, normal); child - diarrhoea two weeks before survey (no, yes)

The following analyses were performed:

- association between sex of household head and the background variables

- association between stunting, underweight, wasting and the 
background variables

- association between stunting, underweight, wasting and the background variables controlled by sex of household head

- logistic regression - to estimate the independent effect of sex of household head on stunting, underweight and wasting by controlling for the effects of the background variables.

\section{Results}

\section{Background characteristics of toddlers}

\section{Societal characteristics}

The sample consists of 1466 toddlers aged 12 - 59 months with an approximately equal number of boys and girls. The majority $(77.1 \%)$ of the children were at least less than three years old at the time of the survey. Most of the children (82.6\%) were of normal birth weight and slightly over a quarter of the children had suffered from diarrhoea two weeks prior to the survey. The children were almost equally $(30 \%)$ distributed among the three regions (Northern, Central and Southern). However, the majority $(75 \%)$ of them came from rural households.

\section{Household Characteristics}

The sample consists of more children from MHH (81\%) than children from FHH (19\%). Malawi is one of the African countries with a relatively high proportion of FHH. For example, according to the 1992 MDHS, about a quarter $(24.6 \%)$ of the households was headed by women. It is noted that $54.2 \%$ of the children came from large households that is households with more than 5 members. Majority of the mothers (52\%) were aged between 1529 years. More than half (58.9\%) of these mothers had received some form of formal education.

A higher proportion (64.8\%) of the children lived in households that did not have access to piped water. Different toilet facilities are used in Malawi, such as flush toilets, traditional pit latrines that are situated either within or outside the compound. Most $(78 \%)$ of the children came from households that had a toilet facility. The traditional pit latrine is the most commonly used toilet facility in Malawi. According to the data on the proxy indicator for economic status, about $80 \%$ of the study children belonged to households that were characterised as poor. 


\section{Household headship and background characteristics}

To what extent does the overall pattern of the above background characteristics of the children differ in male and female-headed households? There were 1188 children in $\mathrm{MHH}$ and 278 children in FHH. Although children from $\mathrm{MHH}$ were evenly distributed in the three regions, the distribution in FHH was a bit uneven (see Table 1). More than $40 \%$ of children from $\mathrm{FHH}$ were residents of the Southern region. $\mathrm{FHH}$ in the northern region had the lowest proportion of children $(27 \%)$. The proportion of children from rural $\mathrm{FHH}$ was higher $(82.7 \%)$ than that of children from rural $\mathrm{MHH}(73.1 \%)$.

Most $(56.0 \%)$ of the children from $\mathrm{MHH}$ belonged to large families. However, the majority $(53.6 \%)$ of the children from $\mathrm{FHH}$ were from small households. Slightly more mothers from FHH (52.5\%) were at least 30 years old compared to $47.5 \%$ from $\mathrm{MHH}$. The educational status of mothers from the two households appears not to differ significantly from each other. There is a clear indication that toddlers from $\mathrm{MHH}$ had better access to water and toilet facilities than those raised in FHH. In addition to the limited source of water and toilet facility, the results on the proxy wealth indicator underscore the general assertion that $\mathrm{FHH}$ tend to be poorer $(87.3 \%)$ than MHH (77.1\%).

The distribution of children according to sex does not appear to be significantly different in the two households. However, significant differences existed between the ages of children in the two households. Children from MHH tended to be slightly younger (12-35 months) $(78.4 \%)$ than those from households headed by females (71.6\%). Regarding birth weight, FHH had a higher proportion of low birth weight babies $(83.6 \%)$ compared to $\mathrm{MHH}$ (78.0\%). Significantly more children from $\mathrm{MHH}(29.0 \%)$ had diarrhoea two weeks prior to the survey compared to children from $\mathrm{FHH}(20.5 \%)$. 
Table 1 Selected Background Characteristics by Sex of Household Head

\begin{tabular}{|c|c|c|}
\hline & $\begin{array}{c}\text { Male Headed } \\
\text { Household } \\
\mathbf{N}=\mathbf{1 1 8 8}\end{array}$ & $\begin{array}{c}\text { Female Headed } \\
\text { Household } \\
\mathrm{N}=278\end{array}$ \\
\hline $\begin{array}{l}\text { Societal } \\
\text { characteristics }\end{array}$ & Percentage & Percentage \\
\hline \multicolumn{3}{|l|}{ Region } \\
\hline Northern & 33.5 & 27.0 \\
\hline Central & 32.6 & 30.2 \\
\hline Southern & 33.9 & 42.8 \\
\hline \multicolumn{3}{|c|}{ Place of residence } \\
\hline Rural & 73.1 & 82.7 \\
\hline Urban & 26.9 & 17.3 \\
\hline \multicolumn{3}{|l|}{$\begin{array}{l}\text { Household } \\
\text { characteristics }\end{array}$} \\
\hline \multicolumn{3}{|l|}{ Household size } \\
\hline Large & 56.0 & 46.4 \\
\hline Small & 44.0 & 53.6 \\
\hline \multicolumn{3}{|l|}{ Source of water } \\
\hline Piped & 37.1 & 26.9 \\
\hline Unpiped & 62.9 & 73.1 \\
\hline \multicolumn{3}{|l|}{ Toilet facility } \\
\hline Any facility & 79.6 & 70.9 \\
\hline No facility & 20.4 & 29.1 \\
\hline \multicolumn{3}{|l|}{ Economic status } \\
\hline Poor & 77.1 & 87.3 \\
\hline Not poor & 22.9 & 12.7 \\
\hline
\end{tabular}




\begin{tabular}{|c|c|c|}
\hline Individual cl & & \\
\hline \multicolumn{3}{|l|}{ Mother's age } \\
\hline $15-29$ & 52.9 & 47.1 \\
\hline $30-49$ & 47.5 & 52.5 \\
\hline \multicolumn{3}{|c|}{ Mother's education } \\
\hline None & 59.7 & 55.8 \\
\hline Some & 40.3 & 44.2 \\
\hline \multicolumn{3}{|l|}{ Sex - child } \\
\hline Male & 51.7 & 51.4 \\
\hline Female & 48.3 & 48.6 \\
\hline \multicolumn{3}{|l|}{ Child - age } \\
\hline $12-35$ & 78.4 & 71.6 \\
\hline $36-59$ & 21.6 & 28.4 \\
\hline \multicolumn{3}{|c|}{ Child - birth weight } \\
\hline Low & 16.4 & 22.0 \\
\hline Normal & 83.6 & 78.0 \\
\hline \multicolumn{3}{|c|}{ Child - diarrhea } \\
\hline Yes & 29.0 & 20.5 \\
\hline No & 71.0 & 79.5 \\
\hline
\end{tabular}

\section{Child nutritional status}

Nutritional status by societal characteristics

Compared to the data on all children under five years as mentioned in the introduction, the prevalence of stunting (HA), underweight (WA) and wasting $(\mathrm{WH})$ was $48.7 \%, 27.2 \%$ and $5.4 \%$ respectively. With respect to the sampled children, the prevalence of stunting, underweight and wasting was found to be $54.2 \%, 31.5 \%$ and $5.9 \%$ respectively.

The data clearly indicates that chronic malnutrition is a national problem both in rural and urban areas. Looking at the three nutritional status indicators, it is clear that stunting is a problem for everyone but what is critical is the huge difference between underweight and acute malnutrition. Children in rural households are more malnourished than those in urban households. The levels of underweight in urban areas is almost half of that present in the rural areas and wasting is almost three times more in rural areas compared to urban areas. Significant regional differences in the nutritional status of children are observed. A higher proportion of children from the Central region were stunted (59.2\%). Underweight $(37.0 \%)$ and wasting $(8.1 \%)$ appear to be more pronounced among children from the Southern region. The Northern region generally exhibits lower prevalence of malnutrition. 


\section{Nutritional status by household characteristics Headship}

It is observed from the results given in Table 2 that the proportion of children categorised as malnourished by each of the three indicators is slightly higher in $\mathrm{FHH}$ than $\mathrm{MHH}$. Yet, none of the relationship is significant. A comparison of these findings with that of Kennedy and Peters (1992) reveals the following: the prevalence of stunting in MHH (62.3\%) found in the study by Kennedy and Peters is higher than that found in this study $(53.6 \%)$. But the proportion of children stunted in $\mathrm{FHH}$ is similar in both studies (55.9\% and $56.6 \%$ respectively). Underweight children in Kennedy and Peters' sample seem to be less malnourished than the children in the current study. Unlike Kennedy and Peters, we did not differentiate between de facto and de jure $\mathrm{FHH}$.

The Malawi data were compared to other countries in Southern Africa. Botswana results reveal that although children from FHH consistently show poor nutritional status, the difference in the prevalence of malnutrition between children from $\mathrm{MHH}$ and $\mathrm{FHH}$ is significant only for underweight children (Ubomba-Jaswa and Belbase, 1996). Unlike the Botswana findings, the South Africa (Bomela, 1999) data show that, the proportion of children underweight and wasted is basically the same in the two households. A significant difference is however, noted for chronic malnutrition in that children from $\mathrm{MHH}$ have a higher prevalence of stunting $(25.7 \%)$ compared to children from FHH (20.4\%). Results from the South Africa study are consistent with results from other countries noted above, but are different from our findings because children in $\mathrm{MHH}$ reflected poorer nutritional status outcomes than children in FHH.

Varying results are also observed from outside southern Africa. Slightly similar to this study's results, in Western Kenya, data on children 12-35 months old revealed that there was no significant relationship between household headship and children's weight and height Z-scores. Nevertheless, they found that few children in FHH were underweight although more children were too short for their age, suggesting that $\mathrm{FHH}$ had lower rates of current but higher rates of past or chronic malnutrition (Onyango, et al, 1994). Results from this study are also in contrast to findings from the Dominican Republic that found that at low income levels children from $\mathrm{FHH}$ tend to achieve superior nutritional status than those in MHH (Johnson \& Rogers, 1993). 


\section{Household size}

According to Bomela (1999) chronic malnutrition (29\%) and underweight $(21 \%)$ are significantly more prevalent in large households compared to small households in South Africa. This is in contrast to findings from this study whereby chronic malnutrition $(55.1 \%)$, underweight $(33.6 \%)$ and wasting $(6.2 \%)$ were more prevalent in small households compared to large households.

\section{Economic status}

The expected pattern that malnutrition tends to be more prevalent among children from poor households than those from households with better economic status was observed in this study. As presented in Table 2, $56.6 \%$ of the children in poor households are stunted compared to $36.8 \%$ found in households that were not poor. Similarly, the proportion of children underweight from poor households is almost twice that of households that are not poor $(17.4 \%)$, while the proportion wasted is almost three times that of children from poor households compared to those from households that were not poor. Though there is no comparable study from Malawi, in Botswana a significant association was established between chronic and current malnutrition and the economic status of the household. (Ubomba-Jaswa and Belbase, 1996). Similarly results from Bomela (1999) suggest that in South Africa, stunting and underweight are more prevalent among children who live in informal structures (shacks and huts) than in formal structures.

\section{Sanitation (water and toilet facilities)}

Since access to sanitation is closely linked to one's economic status, it does not come as a surprise that the nutritional status of children from households that have access to piped water, (stunted $-45.7 \%$, underweight $23.9 \%$, wasted - 3.5\%) appear to be better than those of children in households that use unpiped water $(58.6 \%, 35.4 \%$ and $7.2 \%$ respectively). A similar pattern is observed between availability of toilet facility and the three nutritional status indicators. Thus $51.7 \%$ and $62.5 \%$ of children from households with a toilet facility and households with no toilet facility are found to be stunted respectively. The proportion of children reported underweight and wasted in homes with no toilet facility is about twice that of children from homes with a toilet facility. 


\section{Mother's Characteristics: age and education}

Although no difference is established in the nutritional status of the toddlers according to the age of the mothers, significant association is found between the education status of the mother and the nutritional status of the children. It is likely that the broad categorisation of the age groups could have led to the absence of the expected high prevalence of malnutrition among children of teen mothers. It has been established in the literature of child survival that the educational status of a mother has a strong impact on several child health indicators such as infant mortality, nutritional status and immunisation. Malnutrition seems to be more prevalent among children of mothers with no education - stunted (60\%); underweight $(38.8 \%)$ and wasted $(7.7 \%)$ - compared to children of educated mothers.

\section{Child characteristics (sex, age, birth weight and diarrhoea)}

Although this variable is important in child nutritional studies especially in societies (mainly in South East Asia and parts of Northern Africa) characterised by strong male/son preference it is important to test whether there is any association between gender and nutritional status in Malawi, a country that does not fall in son preference category. Data presented in Table 2 indicate malnutrition seems to be significantly prevalent among male than female toddlers. Chronic malnutrition for boys is $57.4 \%$ compared to $50.8 \%$ for girls, whereas the prevalence of underweight is $34.0 \%$ for boys and $28.9 \%$ for girls. The prevalence of wasting is almost twice as much for boys $(7.0 \%)$ compared to that of girls $(4.8 \%)$. The association between nutritional status and child age is well documented in the literature on child health. The results of this study show that the younger toddlers are significantly less stunted (51.8\%) than toddlers aged 36-59 months (62.3\%). This suggests that stunting tends to manifest itself more strongly as children grow older.

In this study, the vulnerability of low birth weight children is observed in all the three nutritional status indicators. The results reveal that the effect of low birth weight can be felt among both young and old toddlers. The prevalence of stunting for example is $59.3 \%$ for toddlers with low birth weight compared to $35.6 \%$ for the children with normal birth weight. Similarly, more children from the low birth weight category are underweight $(40.7 \%)$ and wasted $(7.7 \%)$ compared to children with normal birth weight. Although no significant relationship between diarrhoea and stunting is observed, the prevalence of underweight $(37.7 \%)$ and wasting $(8.9 \%)$ is found to be more pronounced among children who reported having had diarrhoea two weeks prior to the survey. 
Table 2: Prevalence of Stunting, Underweight and Wasting by the selected Background Characteristics

\begin{tabular}{|c|c|c|c|}
\hline & $\begin{array}{c}\text { Stuntin } \\
\mathrm{g} \\
\mathrm{N}=1466\end{array}$ & $\begin{array}{c}\text { Underweight } \\
N=1466\end{array}$ & $\begin{array}{l}\text { Wasting } \\
\mathrm{N}=1466\end{array}$ \\
\hline \multicolumn{4}{|l|}{$\begin{array}{l}\text { Societal } \\
\text { characteristics }\end{array}$} \\
\hline \multicolumn{4}{|l|}{ Region } \\
\hline Northern & 52.2 & 25.8 & 4.4 \\
\hline Central & 59.0 & 31.3 & 5.1 \\
\hline Southern & 51.6 & 37.0 & 8.1 \\
\hline$p$-value & .046 & .001 & .035 \\
\hline \multicolumn{4}{|l|}{ Residence } \\
\hline Rural & 58.1 & 36.5 & 6.9 \\
\hline Urban & 42.4 & 16.4 & 2.9 \\
\hline $\mathrm{p}$-value & .000 & .000 & .005 \\
\hline \multicolumn{4}{|l|}{$\begin{array}{l}\text { Household } \\
\text { characteristics }\end{array}$} \\
\hline \multicolumn{4}{|l|}{$\begin{array}{l}\text { Sex of } \\
\text { household } \\
\text { head }\end{array}$} \\
\hline Male & 53.6 & 31.3 & 5.7 \\
\hline Female & 56.6 & 33.3 & 6.7 \\
\hline p-value & .385 & .476 & .530 \\
\hline \multicolumn{4}{|l|}{$\begin{array}{l}\text { Household } \\
\text { size }\end{array}$} \\
\hline Large & 53.3 & 29.8 & 5.7 \\
\hline Small & 55.1 & 33.6 & 6.2 \\
\hline p-value & .508 & .128 & .701 \\
\hline \multicolumn{4}{|l|}{$\begin{array}{l}\text { Source of } \\
\text { water }\end{array}$} \\
\hline Piped & 45.7 & 23.9 & 3.5 \\
\hline Unpiped & 58.6 & 35.4 & 7.2 \\
\hline p-value & .000 & .000 & .005 \\
\hline \multicolumn{4}{|l|}{ Toilet facility } \\
\hline Any facility & 51.7 & 27.2 & 4.6 \\
\hline No facility & 62.5 & 45.9 & 10.4 \\
\hline p-value & .001 & .000 & .000 \\
\hline
\end{tabular}




\begin{tabular}{|c|c|c|c|}
\hline \multicolumn{4}{|l|}{$\begin{array}{l}\text { Economic } \\
\text { status }\end{array}$} \\
\hline Poor & 56.6 & 35.1 & 6.8 \\
\hline Not poor & 36.8 & 17.4 & 2.4 \\
\hline $\mathrm{p}$-value & .000 & .000 & .005 \\
\hline \multicolumn{4}{|c|}{$\begin{array}{l}\text { Individual } \\
\text { characteristics }\end{array}$} \\
\hline \multicolumn{4}{|l|}{$\begin{array}{l}\text { Mother's age } \\
\text { (years) }\end{array}$} \\
\hline $15-29$ & 53.6 & 32.5 & 6.5 \\
\hline $30-49$ & 54.9 & 30.4 & 5.2 \\
\hline$p$-value & .624 & .396 & .306 \\
\hline \multicolumn{4}{|l|}{$\begin{array}{l}\text { Mother's } \\
\text { education }\end{array}$} \\
\hline None & 60.3 & 38.8 & 7.7 \\
\hline Some & 49.9 & 26.4 & 4.7 \\
\hline p-value & .000 & .000 & .021 \\
\hline \multicolumn{4}{|l|}{ Child - sex } \\
\hline Male & 57.4 & 34.0 & 7.0 \\
\hline Female & 50.8 & 28.9 & 4.8 \\
\hline p-value & .014 & .038 & .086 \\
\hline \multicolumn{4}{|l|}{$\begin{array}{l}\text { Child - age } \\
\text { (months) }\end{array}$} \\
\hline $12-35$ & 51.8 & 32.6 & 6.9 \\
\hline $36-59$ & 62.3 & 28.0 & 2.8 \\
\hline $\mathrm{p}$-value & .001 & .124 & .006 \\
\hline \multicolumn{4}{|l|}{$\begin{array}{l}\text { Child - birth } \\
\text { weight }\end{array}$} \\
\hline Low & 59.3 & 40.7 & 7.3 \\
\hline Normal & 45.6 & 23.4 & 5.2 \\
\hline $\mathrm{p}$-value & .010 & .000 & .004 \\
\hline \multicolumn{4}{|l|}{$\begin{array}{l}\text { Child - } \\
\text { diarrhoea }\end{array}$} \\
\hline Yes & 56.0 & 37.7 & 8.9 \\
\hline No & 53.5 & 29.2 & 4.8 \\
\hline p-value & .404 & .002 & .004 \\
\hline Total & 54.2 & 31.5 & 5.9 \\
\hline
\end{tabular}




\section{Household headship and child nutritional status}

Our results so far have shown that poor nutritional status is slightly more prevalent among children from $\mathrm{FHH}$ compared to those from $\mathrm{MHH}$ and the difference is not statistically significant. This is an indication that children in FHH may not have poorer nutritional outcomes than their counterparts from $\mathrm{MHH}$. But, several of the societal, household and individual characteristics of mother and child show significant bivariate relationship with stunting, underweight and wasting. It is therefore possible that the results on headship could be masked by important differentials with respect to the societal, household and individual characteristics of the mothers and children.

Hence the interest in the subsequent analysis is to find out whether this overall pattern holds after controlling for the selected background characteristics. Two methods are used. First, the bivariate association between each of the variables and stunting, underweight and wasting is controlled by the sex of household head. Secondly, logistic regression analysis is done to test the independent effect of sex of household head and the other variables on stunting, underweight and wasting. The results of these analyses are presented in Tables 3, 4, 5 and 6.

\section{Independent effect of headship and nutritional status}

As observed from the results shown in Table 3, the only relationship that is significant at the $5 \%$ level is that between headship, economic status (not poor category) and stunting. Chronic malnutrition is commonly observed among children from $\mathrm{MHH}(37.9 \%)$ with better economic status than their counterparts from $\mathrm{FHH}(28.1 \%)$. However, the prevalence of stunting is similar among children from poor $\mathrm{MHH}$ and $\mathrm{FHH}$. 
Table 3: The Prevalence of Stunting in Male and Female Headed Households

\begin{tabular}{|c|c|c|c|}
\hline & $\begin{array}{c}\text { Male } \\
\text { headed } \\
\text { household } \\
1188\end{array}$ & $\begin{array}{c}\text { Female } \\
\text { headed } \\
\text { househol } \\
\text { d } \\
278\end{array}$ & p-value \\
\hline $\begin{array}{l}\text { Societal } \\
\text { characteristics }\end{array}$ & & & \\
\hline \multicolumn{4}{|l|}{ Region } \\
\hline Northern & 52.5 & 50.7 & .777 \\
\hline Central & 57.3 & 66.7 & .121 \\
\hline Southern & 51.2 & 53.1 & .721 \\
\hline \multicolumn{4}{|l|}{ Residence } \\
\hline Rural & 57.7 & 59.6 & .599 \\
\hline Urban & 42.6 & 40.9 & .835 \\
\hline \multicolumn{4}{|l|}{$\begin{array}{l}\text { Household } \\
\text { characteristics }\end{array}$} \\
\hline \multicolumn{4}{|l|}{$\begin{array}{l}\text { Household } \\
\text { size }\end{array}$} \\
\hline Large & 52.3 & 58.2 & .236 \\
\hline Small & 55.1 & 54.9 & .966 \\
\hline \multicolumn{4}{|l|}{$\begin{array}{l}\text { Source of } \\
\text { water }\end{array}$} \\
\hline Piped & 44.5 & 52.9 & .193 \\
\hline Unpiped & 58.9 & 57.2 & .664 \\
\hline \multicolumn{4}{|l|}{ Toilet facility } \\
\hline Any facility & 51.8 & 51.3 & .910 \\
\hline No facility & 60.9 & 67.5 & .296 \\
\hline \multicolumn{4}{|l|}{$\begin{array}{l}\text { Economic } \\
\text { status }\end{array}$} \\
\hline Poor & 58.2 & 59.9 & .638 \\
\hline Not poor & 37.9 & 28.1 & .028 \\
\hline
\end{tabular}




\begin{tabular}{|c|c|c|c|}
\hline $\begin{array}{l}\text { Individual } \\
\text { characteristics }\end{array}$ & & & \\
\hline \multicolumn{4}{|l|}{$\begin{array}{l}\text { Mother's age } \\
\text { (years) }\end{array}$} \\
\hline $15-29$ & 52.6 & 58.3 & .241 \\
\hline $30-49$ & 54.8 & 55.0 & .971 \\
\hline \multicolumn{4}{|l|}{$\begin{array}{l}\text { Mother's } \\
\text { education }\end{array}$} \\
\hline None & 59.9 & 61.7 & .727 \\
\hline Some & 49.4 & 52.4 & .513 \\
\hline \multicolumn{4}{|l|}{ Child - sex } \\
\hline Male & 56.2 & 62.3 & .192 \\
\hline Female & 50.9 & 50.4 & .915 \\
\hline \multicolumn{4}{|l|}{$\begin{array}{l}\text { Child - age } \\
\text { (months) }\end{array}$} \\
\hline $12-35$ & 51.2 & 54.3 & .414 \\
\hline $36-59$ & 62.4 & 61.8 & .931 \\
\hline \multicolumn{4}{|l|}{$\begin{array}{l}\text { Child - birth } \\
\text { weight }\end{array}$} \\
\hline Low & 60.0 & 56.5 & .763 \\
\hline Normal & 45.1 & 48.8 & .535 \\
\hline \multicolumn{4}{|c|}{ Child - diarrhoea } \\
\hline Yes & 56.0 & 55.6 & .947 \\
\hline No & 52.6 & 56.8 & .270 \\
\hline Total & 53.6 & 56.6 & \\
\hline
\end{tabular}

With respect to underweight (Table 4), the exception to the pattern is found with the region, birth weight and sex of the child variables. A significantly higher proportion of children from $\mathrm{MHH}(27.8 \%)$ than children from FHH (15.1\%) were found to be underweight in the Northern region. On the contrary, in the Central region more toddlers were identified as underweight in $\mathrm{FHH}(40.7 \%)$ than those from $\mathrm{MHH}(29.2 \%)$. Whereas no difference was observed among girls, underweight was significantly more prevalent among boys from $\mathrm{FHH}(41.3 \%)$ than boys from $\mathrm{MHH}(32.3 \%)$. Furthermore, low birth weight children seem to be worse off in FHH (52.2\%) than in $\mathrm{MHH}(37.6 \%)$. As far as wasting is concerned, the deviation is 
observed in the following variables: mother's education, diarrhoea and birth weight (see Table 5). Contrary to expectation, wasting is more prevalent among children of mothers with some education from FHH (8.2\%) than their counterparts from $\mathrm{MHH}(4.0 \%)$. Similarly, a significantly higher proportion of children who had diarrhoea $(16.7 \%)$ and those with low birth weight $(17.7 \%)$ from $\mathrm{FHH}$ were considered wasted compared to their counterparts from $\mathrm{MHH}(7.7 \%$ and $4.7 \%$ respectively) (see Table 5).

Table 4: The Prevalence of Underweight in Male and Female

\section{Headed}

Households

\begin{tabular}{|c|c|c|c|}
\hline & $\begin{array}{c}\text { Male } \\
\text { headed } \\
\text { household } \\
1188 \\
\end{array}$ & $\begin{array}{c}\begin{array}{c}\text { Female } \\
\text { headed } \\
\text { household } \\
278\end{array} \\
\end{array}$ & p-value \\
\hline \multicolumn{4}{|l|}{$\begin{array}{l}\text { Societal } \\
\text { characteristics }\end{array}$} \\
\hline \multicolumn{4}{|l|}{ Age (years) } \\
\hline $15-29$ & 31.2 & 38.6 & .108 \\
\hline $30-49$ & 30.9 & 28.6 & .597 \\
\hline \multicolumn{4}{|l|}{ Education } \\
\hline None & 39.9 & 35.0 & .331 \\
\hline Some & 25.2 & 32.0 & .093 \\
\hline Urban & 16.2 & 18.2 & .737 \\
\hline \multicolumn{4}{|l|}{$\begin{array}{l}\text { Household } \\
\text { characteristics }\end{array}$} \\
\hline \multicolumn{4}{|l|}{ Age (years) } \\
\hline $15-29$ & 31.2 & 38.6 & .108 \\
\hline $30-49$ & 30.9 & 28.6 & .597 \\
\hline \multicolumn{4}{|l|}{ Education } \\
\hline None & 39.9 & 35.0 & .331 \\
\hline Some & 25.2 & 32.0 & .093 \\
\hline Unpiped & 36.2 & 32.5 & .334 \\
\hline \multicolumn{4}{|l|}{ Toilet facility } \\
\hline Any facility & 26.8 & 24.4 & .465 \\
\hline No facility & 47.8 & 40.3 & .249 \\
\hline Economic & & & \\
\hline
\end{tabular}




\begin{tabular}{|c|c|c|c|}
\hline \multicolumn{4}{|l|}{ status } \\
\hline Poor & 35.2 & 34.5 & .835 \\
\hline Not poor & 17.2 & 18.8 & .828 \\
\hline \multicolumn{4}{|c|}{$\begin{array}{l}\text { Individual } \\
\text { characteristics }\end{array}$} \\
\hline \multicolumn{4}{|c|}{$\begin{array}{l}\text { Mother's age } \\
\text { (years) }\end{array}$} \\
\hline $15-29$ & 31.2 & 38.6 & .108 \\
\hline $30-49$ & 30.9 & 28.6 & .597 \\
\hline \multicolumn{4}{|l|}{$\begin{array}{l}\text { Mother's } \\
\text { education }\end{array}$} \\
\hline None & 39.9 & 35.0 & .331 \\
\hline Some & 25.2 & 32.0 & .093 \\
\hline \multicolumn{4}{|l|}{ Child - sex } \\
\hline Male & 32.3 & 41.3 & .045 \\
\hline Female & 29.8 & 24.8 & .258 \\
\hline \multicolumn{4}{|c|}{ Child - age (months) } \\
\hline $12-35$ & 32.2 & 34.0 & .631 \\
\hline $36-59$ & 26.9 & 31.6 & .424 \\
\hline \multicolumn{4}{|c|}{$\begin{array}{l}\text { Child - birth } \\
\text { weight }\end{array}$} \\
\hline Low & 37.6 & 52.2 & .0208 \\
\hline Normal & 23.2 & 24.4 & .818 \\
\hline \multicolumn{4}{|l|}{$\begin{array}{l}\text { Child - } \\
\text { diarrhoea }\end{array}$} \\
\hline Yes & 36.5 & 44.4 & .267 \\
\hline No & 28.8 & 30.5 & .621 \\
\hline Total & 31.3 & 33.3 & \\
\hline
\end{tabular}


Table 5: The Prevalence of Wasting in Male and Female Headed Households

\begin{tabular}{|c|c|c|c|}
\hline & $\begin{array}{c}\text { Male } \\
\text { headed } \\
\text { household } \\
1188 \\
\end{array}$ & $\begin{array}{c}\begin{array}{c}\text { Female } \\
\text { headed }\end{array} \\
\text { household } \\
278 \\
\end{array}$ & p-value \\
\hline \multicolumn{4}{|l|}{$\begin{array}{l}\text { Societal } \\
\text { characteristics }\end{array}$} \\
\hline \multicolumn{4}{|l|}{ Region } \\
\hline Northern & 4.7 & 2.7 & .458 \\
\hline Central & 4.9 & 6.2 & .636 \\
\hline Southern & 7.6 & 9.7 & .468 \\
\hline \multicolumn{4}{|l|}{ Residence } \\
\hline Rural & 6.8 & 7.6 & .654 \\
\hline Urban & 2.9 & 2.3 & .803 \\
\hline \multicolumn{4}{|l|}{$\begin{array}{l}\text { Household } \\
\text { characteristics }\end{array}$} \\
\hline \multicolumn{4}{|l|}{ Household size } \\
\hline Large & 5.7 & 5.7 & .999 \\
\hline Small & 5.8 & 7.7 & .397 \\
\hline \multicolumn{4}{|l|}{ Source of water } \\
\hline Piped & 3.3 & 4.3 & .684 \\
\hline Unpiped & 7.2 & 7.2 & .987 \\
\hline \multicolumn{4}{|l|}{ Toilet facility } \\
\hline Any facility & 4.7 & 4.3 & .820 \\
\hline No facility & 9.9 & 11.7 & .658 \\
\hline \multicolumn{4}{|c|}{ Economic status } \\
\hline Poor & 6.7 & 6.9 & .931 \\
\hline Not poor & 2.3 & 3.1 & .784 \\
\hline \multicolumn{4}{|l|}{$\begin{array}{l}\text { Individual } \\
\text { characteristics }\end{array}$} \\
\hline \multicolumn{4}{|l|}{$\begin{array}{l}\text { Mother's age } \\
\text { (years) }\end{array}$} \\
\hline $15-29$ & 6.1 & 8.7 & .287 \\
\hline $30-49$ & 5.3 & 5.0 & .883 \\
\hline
\end{tabular}




\begin{tabular}{|l|c|c|c|}
\hline & & & \\
\hline Mother's education & & & \\
\hline None & 8.4 & 5.0 & .215 \\
\hline Some & 4.0 & 8.2 & .029 \\
\hline & & & \\
\hline Child - sex & & & \\
\hline Male & 6.6 & 8.7 & .380 \\
\hline Female & 4.9 & 4.7 & .922 \\
\hline & & & \\
\hline $\begin{array}{l}\text { Child - age } \\
\text { (months) }\end{array}$ & & & \\
\hline $12-35$ & 6.5 & 8.4 & .364 \\
\hline $36-59$ & 2.8 & 2.6 & .929 \\
\hline & & & \\
\hline Child - birth weight & & & .037 \\
\hline Low & 4.7 & 17.4 & .500 \\
\hline Normal & 5.5 & 3.7 & \\
\hline & & & .032 \\
\hline Child - diarrhoea & & & \\
\hline Yes & 7.7 & 16.7 & \\
\hline No & 5.0 & 4.2 & $\mathbf{6 5 7}$ \\
\hline & & & \\
\hline Total & $\mathbf{5 . 7}$ & & \\
\hline
\end{tabular}

\section{Logistic regression}

Table 6 contains the results of the logistic regression analysis on stunting, underweight and wasting. The odds ratio clearly suggests the likelihood that a toddler from $\mathrm{FHH}$ is found malnourished (stunted, underweight or wasted) is generally the same for a child from MHH. Even though headship does not show a net impact on stunting, the variable that indicates the strongest $(p<0.01)$ net effect on stunting is economic status. Child age and birth weight are the other variables that show significant $(p<0.05)$ net effect on chronic malnutrition. The likelihood that a child from a better economic status household will be stunted is $50 \%$ less likely compared to a child from a poor household. Young toddlers are $43 \%$ less likely to be stunted than older toddlers. Expectedly, the probability that a low birth weight child will be stunted is higher than that of a child with a normal birth weight.

The variables that suggest strong significant $(\mathrm{p}<0.01)$ net effect on underweight are: region, place of residence, toilet facility, birth weight. 
Whereas no difference is observed between children who live in the Central and Southern regions, children in the Northern region are $49 \%$ less likely to be underweight than their counterparts in the Central region. Similarly, children from rural communities are $56 \%$ more likely to be wasted than children that live in urban areas. The likelihood that a child from a home without a toilet facility is found underweight is $52 \%$ more likely than a child from a home with toilet facility. Low birth weight children are 55\% more likely to be found as too thin for their age compared to children with normal birth.

With regard to wasting, only two of the selected variables: region and child age show significant net effect on wasting. The results suggest that the net impact of the significant variables on wasting is more moderate $(\mathrm{p}<$ $0.05)$ than those of underweight $(\mathrm{p}<0.01)$ and stunting. Children from Southern $(68 \%)$ and Northern $(65 \%)$ regions are less likely to manifest wasting than toddlers who live in the Central region. Unlike the pattern found with stunting, younger toddlers are 9.4 times more likely to be too thin for their height than older toddlers. 
Table 6: Logistic Regression Estimates of Sex of Household Head and Background characteristic on Stunting, Underweight and Wasting

\begin{tabular}{|c|c|c|c|}
\hline & Stunting & Underweight & Wasting \\
\hline $\begin{array}{l}\text { Variables in the } \\
\text { model }\end{array}$ & \multicolumn{3}{|c|}{ Exp (B) and significance levels } \\
\hline $\begin{array}{l}\text { Sex of household } \\
\text { head (ref. = Male) } \\
\text { Female }\end{array}$ & $.9991 \mathrm{~ns}$ & $.9684 n s$ & $1.1078 \mathrm{~ns}$ \\
\hline $\begin{array}{l}\text { Region (ref. = } \\
\text { Central) } \\
\text { Northern } \\
\text { Southern }\end{array}$ & $\begin{array}{l}1.1532 \mathrm{~ns} \\
1.4661^{*}\end{array}$ & $\begin{array}{l}.5104^{* * *} \\
.9646 \mathrm{~ns}\end{array}$ & $\begin{array}{l}.3287^{* *} \\
.3516^{* *}\end{array}$ \\
\hline $\begin{array}{l}\text { Place of residence } \\
\text { (ref. = Urban) } \\
\text { rural }\end{array}$ & $.6747^{*}$ & $.4478^{* * *}$ & $.6618 \mathrm{~ns}$ \\
\hline $\begin{array}{ll}\text { Household } & \text { size } \\
\text { (ref. = Small) } & \\
\text { large } & \\
\end{array}$ & $.8476 \mathrm{~ns}$ & $.9557 \mathrm{~ns}$ & $1.1031 \mathrm{~ns}$ \\
\hline $\begin{array}{l}\text { Mother's age (ref. } \\
=15-29) \\
30-49\end{array}$ & $1.0742 \mathrm{~ns}$ & $.9863 \mathrm{~ns}$ & $.7314 \mathrm{~ns}$ \\
\hline $\begin{array}{l}\text { Mother's } \\
\text { education (ref. = } \\
\text { Some education) } \\
\text { none }\end{array}$ & $.8027 n s$ & $.8927 n s$ & $1.4540 \mathrm{~ns}$ \\
\hline $\begin{array}{lll}\text { Water } \quad \text { (ref. }= \\
\text { Piped) } \\
\text { unpiped }\end{array}$ & $1.1127 \mathrm{~ns}$ & $1.1080 \mathrm{~ns}$ & $.5745 \mathrm{~ns}$ \\
\hline $\begin{array}{l}\text { Toilet facility (ref. } \\
=\text { Any facility) } \\
\text { no facility }\end{array}$ & $.6455^{*}$ & $.4825^{* * *}$ & $.6047 \mathrm{~ns}$ \\
\hline $\begin{array}{l}\text { Economic status } \\
\text { (ref. = Not poor) } \\
\text { poor }\end{array}$ & $.5030 * * *$ & $.6137^{*}$ & $.4598 \mathrm{~ns}$ \\
\hline $\begin{array}{l}\text { Child age (ref. = } \\
\text { 12-35 months) } \\
\text { 36-59 months }\end{array}$ & $.5793^{* *}$ & $1.1882 \mathrm{~ns}$ & $9.4022^{* *}$ \\
\hline $\begin{array}{l}\text { Child sex (ref. = } \\
\text { Male) } \\
\text { Female }\end{array}$ & $1.1257 \mathrm{~ns}$ & $1.0034 \mathrm{~ns}$ & $1.4002 \mathrm{~ns}$ \\
\hline
\end{tabular}




\begin{tabular}{|l|l|l|l|}
\hline $\begin{array}{l}\text { Child -birth weight } \\
\text { (ref. = Normal) } \\
\text { small }\end{array}$ & $.5793^{* *}$ & $.4582^{* * *}$ & $.7352 \mathrm{~ns}$ \\
\hline $\begin{array}{l}\text { Child - diarrhoea } \\
\text { (ref. = No) } \\
\text { yes }\end{array}$ & $.7291 \mathrm{~ns}$ & $.7712 \mathrm{~ns}$ & $.8551 \mathrm{~ns}$ \\
\hline
\end{tabular}

${ }^{*} \mathrm{p}<.10 ;{ }^{* *} \mathrm{p}<.05 ;{ }^{* * *} \mathrm{p}<.01$

\section{Discussion}

\section{Economic}

Malawi is one of the world's poorest countries with a GNI per capita of U\$170 and among the bottom 10\% of the countries on the Human Development Index. Poverty is highly widespread in both rural and urban households. There is heavy reliance on subsistence farming which is in turn affected by drastic environmental changes such as drought and floods making food production quite erratic. Agriculture employs almost half of those in paid employment, and supports at least $85 \%$ of the population Household food insecurity (which tends to affect both children and adults) stems from both inadequate and insufficient food production as well as the lack of purchasing power to obtain food from the market. Most households therefore tend to suffer from food insecurity resulting in high levels of chronic malnutrition.

Expectedly, poor households are usually not in a position to afford good quality foods such as those rich in proteins, vitamins. As a result, poor households tend to depend almost solely on maize, both for adult and children meals. This chronic poverty makes children vulnerable with respect to decision making and allocation of household resources. Adequate feeding, time for preventive and curative care for children becomes critical because of the cost involved and the number of times such care is needed.

\section{Region}

Data on child mortality in the Northern region support the current result of better child nutritional status in the region. What are some of the contributing factors to the low levels of child malnutrition and mortality in the Northern region? Despite the relatively low level of development in the Northern region compared to the Central and Southern regions, literacy levels among both men and women are higher in the Northern region compared to two regions. Comparatively, the Northern region has more health facilities. Since farming is more prominent in the Northern region, 
household food security tends to be better in the other regions. Furthermore, the low population density coupled with the environmental conditions contributes to the high resistance to the breeding of disease transmitting parasites in the Northern region.

\section{Residence}

Even though the long term effect of inadequate food intake and associated frequent illnesses is manifested in the widespread of stunting, the results clearly indicate that current malnutrition is a major problem among rural children. Besides the general poverty, rural households have their added burden of lack of access to basic social and health resources (clean drinking water, clinics, sustainable employment, etc) needed to improve the lives of the residents.

Ironically, rural households tend to be food insecure with little purchasing power: They do not have adequate food of their own and neither do they have the means to buy it. Such deprivation can result in frequent starvation in very poor households. Many rural households depend on farming but they tend to have less land for their subsistence farming as a result they generally rely on seasonal ganyu (casual) labour income rather than their own farm production. Usually these farmers seek seasonal employment during December and January. This is also the time when the farmers are supposed to be busy cultivating their own plots. Some maintain their modest plots, but often at the expense of neglecting them. This results in lower productivity thus perpetuating poor economic situations thereby increasing the problem of malnutrition (UNICEF/ Malawi Government, 1993).

\section{Sanitation}

Inadequate access and utilisation of piped borne water and toilet facilities often expose household members to both water-borne and watershed diseases. Personal, domestic and food hygiene are often compromised, thereby increasing the risk of diarrhoeal and other infectious diseases often associated with malnutrition. It is therefore not surprising that the nutritional status of children from households that have access to a toilet facility is better than their counterparts that do not have a facility. While different households can have access to the same community pipe stand, provision of toilet facility individuals tends to be an individual responsibility. The type and location of toilet facility to a large extent, influences the management of excreta disposal and hand washing behaviour - risk factors in childhood infectious diseases. 


\section{Child characteristics: birth weight and age}

Low birth weight is a major cause of illness and death among children. Its health impact does even stretch into adulthood. It does not even come as a surprise that the vulnerability of low birth babies is observed in the net impact it shows on underweight and stunting. The net effect of child age on nutritional status has been well documented. Growing children have many nutritional needs and where these needs are not met, they become at risk of infections and chronic malnutrition that tend to impair their growth. The effect of weaning and the introduction of children to solid food and adult diet become very crucial for toddlers.

The basic staple food nsima is low in caloric content. Often, when children are weaned, they are fed phala (thin porridge), a thin gruel prepared from nsima. As the child grows, it is gradually thickened. Most households cannot afford to add groundnut paste, fish oil or eggs that are recommended to make the porridge more nutritious. Furthermore, it is required that children should be fed frequently. However, for most households, this is not possible due to inadequate resources (time, fuel wood) as such most children's meal times are tied to that of adult meals (UNICEF/Malawi Government, 1993). These children are more at a higher risk of childhood infections such as diarrhoea and other intestinal infections, as a result of contamination from water and foods.

In addition, older children could be regarded as the survivors of this onslaught whereby they are gaining immunity. Generally, toddlers in Malawi are cared for by mothers, older siblings and grandmothers, (formal day care for pre-school children is not a common practice in Malawi) unlike infants who are more dependent on mothers and have breastfeeding and maternal immunity advantage. Toddlers are at the age where they become more exposed to infections from other children as they start mixing and playing with them and exploring their immediate home environment.

In a country like Malawi, as is the case with most countries in subSaharan Africa, the results underscore the importance of growth monitoring not only for infants but also in toddlers. Although the growth of children is supposed to be monitored by routine weighing of the children, from infancy to pre-school time (around the age of 6 years), most toddlers do not benefit from this national health programme as mothers often stop taking their children for weighing after the completion of the basic immunisation schedule. 


\section{Conclusion and Recommendations}

The expected high prevalence of stunting and underweight among children from most sub-Saharan countries was observed among toddlers in Malawi. A higher proportion of malnourished children (WA and $\mathrm{WH}$ ) were found in the Southern region compared to the Central and the Northern region. Maternal education, access to adequate water and toilet facilities, economic status and birth weight were found to be associated with the nutritional status of the toddlers. Children who did not had diarrhoea two weeks prior to the survey were found to be less underweight and wasted. However, in both the bivariate and the logistic regression analyses sex of household head did not show any association or net impact on any of the three nutritional status indicators, suggesting that although FHHs appeared to be poorer than MHHs nutritional status outcomes of toddlers in the two households were found to be similar.

Studies which have examined the impact of sex of household head and nutritional status of children have found varying results. Issues that are likely to affect the analysis between headship and nutritional status center around the operational definition of headship and variables used to measure income, economic status and other related concepts. The concept headship in this study was not demarcated into de facto and de jure as analyzed in other studies. There seems to be limitations regarding the use of data from DHS to analyze the impact of household headship on nutritional status. The important factors being: lack of direct questions on sources and levels of income. Secondly, the in built effect of the headship hypothesis which shows a strong role of decision making and allocation of household resources, data are not available in MDHS.

Unlike sex of household head, the following variables showed significant net impact on nutritional status indicators: economic status, residence, region, toilet facility and birth weight and child's age. The findings in this study clearly demonstrate that poverty at the household level is the major determinant of chronic malnutrition resulting in stunting in children. An important finding is that children from economically better households headed by women exhibit better nutritional status than counterparts from male headed. This suggests that children benefit more from resource allocation in female headed households than in male headed households. With respect to underweight, besides birth weight and access to toilet facility, the major factor is the geographical location of the child - the region in which the child resides in and also whether the child is in the rural or urban area. The results on the regions are quite interesting. The Northern region, the least developed of the three regions, exhibited the lowest levels of malnutrition as indicated by the three nutritional status indicators. This 
pattern corresponds with the mortality of children where infant and underfive mortality rates are lowest in the Northern region. Among the probable explanations for this development-health paradox are: high levels of literacy for women, more accessible health facilities, such as clinics, dispensaries etc, low population density, balanced climate in the Northern region compared to the Central and Southern regions.

In view of the above the following recommendations are made.

- The results from this study clearly underscore the crucial role of poverty in the nutrition of children. In addition to the several private organisations working in poverty alleviation projects, Malawi has a government Poverty Reduction Strategy. No doubt there are several dimensions to such a strategy. We endorse the need for income generating activities. Yet we suggest the call to go beyond that and look at areas like management of household resources (human, goods, services, time, money, etc). This is crucial particularly in the context of scarce resources. In such endeavours, caution should be taken to avoid stereotyping so that both males and females are given equal opportunity to participate.

- These poverty alleviation programmes should include the provision and the use of basic appropriate sanitation systems - water supply, toilet facility, garbage disposable, etc.

- With the threatened food shortages as a result of cyclic droughts and floods, the management of post-harvest production at governmental and household levels cannot be overemphasised. Household food insecurity plays a crucial role in malnutrition, not only in children but also in adults.

- Health promotion programmes aimed at maternal and child health such as micronutrient supplements, fortified weaning and general foods, ante-natal care and growth monitoring should be strengthened and appropriately utilised.

- Gender and generational stereotyping could either thrive or be weakened in the context of social, economic, health and political crises resulting in the dis-functioning and even collapse of some traditional as well as modern institutions. All types of indicators suggest that household structures and organisations are in distress in Malawi. One of such manifestations is registered in the persistent high malnutrition in her children. Both males and females, young and old need to be given equal opportunity to be empowered to promote national survival. 


\section{REFERENCES}

Bomela, N. J. 1999. Child Mutritional Status and Household Patterns in South Africa. Pretoria: University of Pretoria. (Master's thesis).

Ebrahim G J. 1992. Practical Mother and Child Health in Developing Countries. $4^{\text {th }}$ ed., London \& Basingstoke: Macmillan Press Ltd.

Engle, P.L. 1995. "Child caregiving and infant and pre-school nutrition". In Andersen, Pelletier and Alderman (eds.). Child Growth and Nutrition in Developing Countries: Priorities for Action. Ithaca: Cornell University Press.

Foster, P. 1992. The World Food Problem. Tackling the Causes of Undernutrition in the Third World. US: Lynne Rienner Publishers, Inc.

Government of Malawi. 2002. Malawi Poverty Reduction Strategy Paper. Zomba: Government Printers pp. 63.

Himes, J. H. 1991. Anthropometric Assessment of Nutritional Status. New York: WileyLiss.

Johnson, F.C. and Rogers, B. L. 1993. “Children's nutritional status in female headed households in the Dominican Republic". Social Science and Medicine, 37 (11): 1293 1301.

Kennedy, E \& Peters, P. 1992. "Household food security and child nutrition: The interaction of income and gender of the household head". World Development, 20 (8): 1077-1085

Lloyd, C. B. \& Gage-Brandon, A.J. 1993. Women's role in maintaining households: family welfare and sexual inequality in Ghana. Population Studies. 47. (1): 115-132.

Madise, N. J. \& Mpoma, M. 1997. "Child malnutrition and feeding practices in Malawi". Food and Nutrition Bulletin, 18 (2): 190-201

Madise, N.J., Mathews, Z. \& Margetts, B. 1997. "Heterogeneity of child nutritional status between households: A comparison of six-sub-Saharan African countries". Population Studies, 53.

Malawi National Statistics Office. 1994. Malawi Demographic Health Survey 1992: Summary Report. Malawi National Statistics Office and Macro International, Inc

Malawi National Statistics Office. 1994. Malawi Demographic Health Survey 1992. Malawi National Statistics Office and Macro International, Inc

Malawi National Statistics Office. 2001. Malawi Demographic Health Survey. 2001. Malawi National Statistics Office and Macro International, Inc

Manda, S.O.M. 1999. "Birth intervals, breastfeeding and determinants of child 
mortality in Malawi". Social Science and Medicine, 48: 301-312.

Miller, D. 1996. Matrilineal and social change: How are Malawian women managing? (http://www.brocku.ca/epi/casid/miller.htm)

Onyango, A., Tucker, K \& Eisemon, T. 1994. "Household headship and child nutrition: A case study of western Kenya". Social Science and Medicine, 39 (12):16331639.

Pelletier, D.L. \& Msukwa, L. A. H. 1991. "Malawi maternal and Child Nutrition study: study design and anthropometric characteristics of children and adults". American Journal of Human Biology, 3: 347-361.

Pelletier, D. L. \& Msukwa, L.A.H. 1991. “The use of National sample surveys for nutritional surveillance: Lessons from Malawi National sample Survey of Agriculture". Social Science and Medicine, 32 (8): 887 - 898

Pelletier, D. L. \& Msukwa, L. A. H. 1991. "Sources of measurement variation in child Anthropometry in the Malawi Maternal and child nutrition study". American Journal of Biology, 3: 227-237.

Per Pinstrup, David Pelletier \& Harold Adelman. 1995. Child growth and nutrition in developing countries. Priorities for Action. USA: Cornell University Press

Quinn, V. J. Chiligo, M. \& Gittinger, J. P. 1990. “Malnutrition, household income and food security in rural Malawi". Health Policy and Planning, 5 (2): 139-148.

Quinn, V. J. Chiligo-Mpoma, M. O. Simler, K. \& Milner, J. 1995. “The growth of Malawian pre-school children from different socio-economic groups". European Journal of Clinical Nutrition, 49: 66-72.

Ruel, M. T. Habitch, J. Per Pinstrup-Andersen \& Grohn, Y. 1992. “The mediating effect of maternal nutrition knowledge on the association between maternal schooling and child nutritional status in Lesotho". American Journal of Epidemiology, 135 (8): 904-914

Ubomba-Jaswa, S.R. and K. Belbase (1996): Determinants of Child Nutritional Status in Botswana. UNICEF, Botswana

UNICEF. 1998. The State of World's Children 1998. New York: United Nations

UNICEF. 1998. Vitamin A Mortality Reduction Project Consolidated Final Report: Highlights of Country Achievements. Malawi: Breaking new ground in policy and programmes. New York: United Nations.

United Nations/Malawi Government. 1993. Situation Analysis of Poverty in Malawi. Zomba. Government Printer.

UNDP. 1998. United Towards Vision 2020: United Nations Development Assistance for poverty eradication in Malawi. (www.sdnp.org.mw/undp/UNS/UNDAF). 
http://aps.journals.ac.za

World Food Programme. 1998. Country Programme for Malawi (1998) 